\title{
Chronic anthracycline cardiotoxicity: haemodynamic and histopathological manifestations suggesting a restrictive endomyocardial disease
}

\author{
S A MORTENSEN,* H S OLSEN, $\dagger$ U BAANDRUP† \\ From the ${ }^{\star}$ Cardiovascular Laboratory of Medical Department B, Rigshospitalet, Copenhagen, Denmark; and \\ the †University Institute of Pathology, Aarhus Municipal Hospital, Denmark
}

SUMMARY Of 38 patients referred with suspected cardiotoxicity after administration of antineoplastic drugs, 11 patients with signs of manifest or latent anthracycline cardiotoxicity were selected for heart catheterisation with endomyocardial biopsy. Ultrastructural abnormalities of the myocytes with myofibrillar loss and cytoplasmic vacuolation were present in most patients and these findings were more pronounced in biopsy specimens from the left ventricle. Surprisingly, light microscopy showed considerable fibrous thickening of the endocardium in 10 of 11 patients, primarily in the left ventricle. These morphological findings together with the echocardiographic and the haemodynamic data suggest that chronic anthracycline cardiotoxicity is a restrictive endomyocardial disease. The biochemical mechanisms responsible for endocardial fibrosis are unknown, but drug induced damage to the endocardium, possibly mediated via hormonal or humoral agents, may feature in the initial phase of the toxic process. The present observations contribute toward the understanding of the pathophysiology of human anthracycline cardiotoxicity.

The clinical usefulness of daunorubicin and doxorubicin (Adriamycin) is limited by dose dependent cardiac damage (anthracycline cardiotoxicity). ${ }^{12}$ Doxorubicin doses of up to $550 \mathrm{mg} / \mathrm{m}^{2}$ body surface area (empirical cumulative dose) are usually not cardiotoxic. A subset of patients, however, shows signs of cardiac damage at lower doses, especially when there are contributory risk factors, for example, previous mediastinal irradiation. ${ }^{3}$

Limitation of the doxorubicin dose may deprive the patient of effective and extended cancer chemotherapy. Attempts to resolve this problem have included alterations of the dose schedule of doxorubicin and the development of analogues (class II anthracyclines) with reduced cardiotoxicity. Aclacinomycin (Aclarubicin) ${ }^{4}$ and $4^{\prime}$-epidoxorubicin (Epirubicin) $^{5}$ are interesting new class II drugs. A

Requests for reprints to Dr S A Mortensen, Medical Department B, 2014, Rigshospitalet Blegdamsvej 9, DK-2100 Copenhagen $\emptyset$, Denmark.

Accepted for publication 19 November 1985 safe maximum dose for both drugs has yet to be established; for Epirubicin it is probably about $1000 \mathrm{mg} / \mathrm{m}^{2}$.

Various cardiological approaches have been used for the early detection of cardiac dysfunction during doxorubicin treatment. Apart from endomyocardial biopsy, they have proved to be of limited value. ${ }^{6}$ In this context histological investigation of myocardial tissue is the most reliable method of monitoring heart function. It allows the total cumulative dose to be adjusted for the individual patient before obvious clinical signs of damage appear. The use of cardiac biopsy has, however, been restricted to centres with specialised histopathological facilities. ${ }^{78}$ Fully developed anthracycline cardiotoxicity is usually described clinically as congestive cardiomyopathy. ${ }^{129}$ In rare cases there is evidence of a restrictive pattern, but this has mainly been attributed to previous radiotherapy. ${ }^{910}$ The present study was undertaken to describe severe human anthracycline cardiotoxicity. Our objectives were $(a)$ to obtain a combined haemodynamic and histopathological classification of the condition, with both right and 
left heart catheterisation data; $(b)$ to confirm that myocardial inflammation is not a feature of severe human anthracycline cardiotoxicity, ${ }^{3}$ despite this feature having been seen in animal experiments ${ }^{11}$; (c) to discover whether the morphological picture of cardiotoxicity seen during anthracycline chemotherapy $^{3}$ is different at the time of clinical heart failure, often when treatment has been discontinued (d) to determine, by examination of biopsy material, the ventricular wall in which morphological evidence of cardiotoxicity is most clearly expressed-that is, is the right ventricular septum a reliable sampling area?

\section{Patients and methods}

Since 1980,48 patients have been referred from various oncological haematological departments in Copenhagen with suspected cardiotoxicity caused by antineoplastic drugs. The clinical manifestations of cardiotoxicity in the first 38 of these patients have been reported elsewhere. ${ }^{12}$ The 11 selected patients described in the present report comprise all cases undergoing haemodynamic investigations with endomyocardial biopsy (during a two year periodfrom February 1982 to February 1984). There were eight women and three men, mean age 51 years (range 29-60). The indications for biopsy were overt congestive heart failure (manifest cardiotoxicity) $(\mathrm{n}=7)$; suspected anthracycline damage at less than the empirical dose $(n=2)$; and to establish a means of cardiac monitoring during continued chemo- therapy at doses in excess of the empirical dose $(\mathrm{n}=2)$.

Table 1 shows the initial patient characteristics with the following clinical data: the site of the primary neoplasm, risk factors, and cumulative anthracycline dose; and results from electrocardiographic and chest $x$ ray examinations and the New York Heart Association functional class (when they were admitted for heart catheterisation). M mode and cross sectional echocardiograms were obtained with standard techniques. ${ }^{13}$ We used gated blood pool scans (radionuclide angiocardiography) to measure left ventricular ejection fractions at rest and during supine submaximal exercise. ${ }^{1+}$

Right and left heart catheterisation was performed and the cardiac index (Fick) was determined. I.eft ventricular angiocardiography and thoracic aortography were carried out. Transvascular endomyocardial biopsy specimens of the right ventricle or the left ventricle or both were obtained with King's bioptome ${ }^{15}$ and a modified long sheath technique from the groin. A total of four to six biopsy specimens from each patient were fixed in formalin $\left(10^{\prime \prime}{ }_{11}\right)$ and processed for light microscopy (paraffin sections); in nine patients at least two samples were fixed in cacodylate buffered glutaraldehyde $\left(3^{\prime \prime}{ }^{\prime}\right)$ for later electron microscopy according to previously described techniques. ${ }^{16}$ The histopathological evaluation and the electronmicroscopic grading, which corresponded to the Billingham scale ${ }^{3}$ (that is 0,1 , $1.5,2,2.5$, and 3 ) were performed without any knowledge of the clinical and hacmodynamic data,

ble 1 Cinical details of 11 patients with anthracveline cardiotoxicity

\begin{tabular}{|c|c|c|c|c|c|c|c|c|c|}
\hline $\begin{array}{l}\text { Patient } \\
\text { lio }\end{array}$ & $A g^{\prime}$ & $\operatorname{Sex}$ & Diagnosis & Risk factors & $\begin{array}{l}\text { Total dose of } \\
\text { anthracviline }\end{array}$ & $\begin{array}{l}\text { NYHA } \\
\text { class }\end{array}$ & $I: C(;$ & $\begin{array}{l}\text { Chest } \\
x \text { ray }\end{array}$ & (Outcome \\
\hline 1 & 33 & $\mathrm{~F}$ & $\begin{array}{l}\text { Pancreatic } \\
\text { carcinoma }\end{array}$ & - & $\begin{array}{l}\text { Doxorubicin } \\
550 \mathrm{mg} \mathrm{m}^{2}\end{array}$ & I & $\mathrm{SI}$ & No cardiomegaly & Died of cancer \\
\hline$?$ & 40 & $M$ & $\begin{array}{l}\text { I.ung } \\
\text { carcinoma }\end{array}$ & - & $\begin{array}{l}\text { 4-epidoxorubicin } \\
360 \mathrm{mg} \mathrm{m}^{2}\end{array}$ & II & $\begin{array}{l}\text { Negative } \\
\text { I waves }\end{array}$ & No cardiomegaly & Died of cancer \\
\hline 3 & 55 & $\mathrm{~F}$ & $\begin{array}{l}\text { Breast } \\
\text { carcinoma }\end{array}$ & $\begin{array}{l}\text { Irradiation, } \\
\text { cyclophosphamide }\end{array}$ & $\begin{array}{l}\text { Doxorubicin } \\
575 \mathrm{mg} \mathrm{m}^{2}\end{array}$ & IV & $\begin{array}{l}\mathrm{SI} \text { and low } \\
\mathrm{R} \text { waves }\end{array}$ & Cardiomegaly & Sudden death \\
\hline$t$ & 50 & $\mathrm{~F}$ & $\begin{array}{l}\text { Parotid } \\
\text { carcinoma }\end{array}$ & - & $\begin{array}{l}\text { Doxorubicin } \\
550 \mathrm{mg} \mathrm{m}^{2}\end{array}$ & I & $\begin{array}{l}\mathrm{ST} \text { and low } \\
\mathrm{R} \text { waves }\end{array}$ & No cardiomegaly & $\begin{array}{l}\text { Died of cancer } \\
\text { C } \mathrm{HF}\end{array}$ \\
\hline ; & 29 & $\mathrm{~F}$ & $\begin{array}{l}\text { Soft tissue } \\
\text { sarcoma }\end{array}$ & Cyclophosphamide & $\begin{array}{l}\text { Doxorubicin } \\
550 \mathrm{mg} \mathrm{m}^{2}\end{array}$ & IV & $\begin{array}{l}S \mathrm{I} \text { and low } \\
\mathrm{R} \text { waves }\end{array}$ & Cardiomegaly & Alive NYHA 1 \\
\hline 6 & 58 & $\mathrm{~F}$ & $\begin{array}{l}\text { Ovarian } \\
\text { carcinoma }\end{array}$ & Cyclophosphamide & $\begin{array}{l}\text { Doxorubicin } \\
530 \mathrm{mg} \mathrm{m}^{2}\end{array}$ & IV & $\begin{array}{l}\mathrm{SI} \text { and low } \\
\mathrm{R} \text { waves }\end{array}$ & (Cardiomegaly) & Alive NYHA II \\
\hline$i$ & 55 & $M$ & $\begin{array}{l}\text { I.ung } \\
\text { carcinoma }\end{array}$ & 一 & $\begin{array}{l}\text { 4-epidoxorubicin } \\
1533 \mathrm{mg} \mathrm{m}^{2}\end{array}$ & III & $\begin{array}{l}\mathrm{ST} \text { and low } \\
\mathrm{R} \text { waves }\end{array}$ & No cardiomegaly & $\begin{array}{l}\text { Died of cancer } \\
\text { CHF }\end{array}$ \\
\hline 8 & 57 & $\mathrm{~F}$ & $\begin{array}{l}\text { ()arian } \\
\text { carcinoma }\end{array}$ & Cyclophosphamide & $\begin{array}{l}\text { Doxorubicin } \\
564 \mathrm{mg} \mathrm{m}^{2}\end{array}$ & II & $\begin{array}{l}\mathrm{SR} \text { and low } \\
\mathrm{R} \text { waves }\end{array}$ & No cardiomegaly & Alive NYHA I \\
\hline 9 & 53 & $\mathrm{~F}$ & $\begin{array}{l}\text { ()arian } \\
\text { carcinoma }\end{array}$ & Cyclophosphamide & $\begin{array}{l}\text { Doxorubicin } \\
550 \mathrm{mg} \mathrm{m}^{2}\end{array}$ & II & $\begin{array}{l}\text { SI and negative } \\
\text { T waves }\end{array}$ & (Cardiomegaly) & Sudden death \\
\hline 10 & 60 & $M$ & $\begin{array}{l}\text { I.ung } \\
\text { mesothelioma }\end{array}$ & $\begin{array}{l}\text { Arterial } \\
\text { hypertension }\end{array}$ & $\begin{array}{l}\text { Doxorubicin } \\
550 \mathrm{mg} \mathrm{m}^{2}\end{array}$ & II & $\begin{array}{l}\mathrm{SI}^{\circ} \text { and low } \\
\mathrm{R} \text { waves }\end{array}$ & (Cardiomegaly) & Alive NYHA I \\
\hline !1 & 53 & $\mathrm{I}:$ & $\begin{array}{l}\text { I.ung } \\
\text { carcinoma }\end{array}$ & $-\cdots$ & $\begin{array}{l}\text { 4-epidoxorubicin } \\
645 \mathrm{mg} \mathrm{m}^{2}\end{array}$ & II & $\begin{array}{l}\mathrm{SR} \text { and negative } \\
\text { I waves }\end{array}$ & (Cardiomegaly) & Died of cancer? \\
\hline
\end{tabular}

ST, sinus tachycardia; SR, sinus rhythm; CHF, congestive heart failure; NYHA, New York Heart Association. Parentheses indicate presence of slight 8 ardiomegaly 
'Table 2 Echocardiographic, scintigraphic, and haemodynamic data in 11 patients with anthracycline' cardiotoxicity

\begin{tabular}{|c|c|c|c|c|c|c|c|c|c|c|c|c|c|c|}
\hline \multirow{2}{*}{$\begin{array}{l}\text { Putient } \\
\text { Nis }\end{array}$} & \multirow{2}{*}{$\begin{array}{l}I: I) I) \\
(m)\end{array}$} & \multirow{2}{*}{$\begin{array}{l}E S I) \\
(\mathrm{cm})\end{array}$} & \multirow{2}{*}{$\begin{array}{l}\text { MSS.S } \\
\text { (cm) }\end{array}$} & \multirow{2}{*}{$\begin{array}{l}R I^{\prime} \\
(m)\end{array}$} & \multirow{2}{*}{$\begin{array}{l}L A \\
(\mathrm{~cm})\end{array}$} & \multicolumn{2}{|l|}{ Gated scan } & \multirow{2}{*}{$\begin{array}{l}R A \\
(\text { mm } H g) \\
\text { mean }\end{array}$} & \multicolumn{3}{|c|}{ Systolic diustolic pressure } & \multirow{2}{*}{$\begin{array}{l}\text { Angiography } \\
\text { LVEF (" })\end{array}$} & \multicolumn{2}{|c|}{$\begin{array}{l}\text { Cardiacindex } \\
\text { ll/min }\end{array}$} \\
\hline & & & & & & $\begin{array}{l}\text { I.IEE (" ") } \\
\text { rest) }\end{array}$ & $\begin{array}{l}\text { I.VEF " ", } \\
\text { (exercise' }\end{array}$ & & $\begin{array}{l}R V \\
(m m H g)\end{array}$ & $\begin{array}{l}P A \\
m m H g\end{array}$ & $\begin{array}{l}L V^{\prime} \\
(m m H g)\end{array}$ & & & $n$ \\
\hline 1 & $4 \cdot 2$ & $3 \cdot 0$ & $(0) 4$ & $2 \cdot 0$ & $2 \cdot 5$ & - & - & 2 & 283 & 268 & 1053 & - & $(5 \cdot 2)$ & $\overline{\bar{c}}$ \\
\hline 2 & $5 \cdot 3$ & 3.5 & 0.5 & $2 \cdot 3$ & $3 \cdot 3$ & - & - & 5 & 347 & 3415 & 1157 & 59 & 3.8 & $\frac{\omega}{2}$ \\
\hline 3 & $5 \cdot 5$ & $4 \cdot 6$ & $2 \cdot()$ & $2 \cdot 7$ & $4 \cdot()$ & 19 & 23 & 2 & 352 & 3013 & 9011 & - & $1 \cdot 4$ & Q \\
\hline 4 & \multicolumn{5}{|c|}{ Impossible: lung metastases } & 47 & 47 & () & 240 & 198 & 1182 & 35 & $3 \cdot 3$ & 1 \\
\hline 5 & $5 \cdot 3$ & 4.5 & $1 \cdot 2$ & $3 \cdot 0$ & 3.5 & 17 & 21 & 12 & $37 \quad 12$ & 3821 & 8522 & 23 & 1.6 & $\omega$ \\
\hline 0 & $5 \cdot 8$ & $5 \cdot 1$ & $2 \cdot 2$ & $1 \cdot 8$ & $4 \cdot 6$ & 18 & 18 & 0 & 23.3 & 2410 & 8519 & 18 & $2 \cdot 4$ & $\vec{\sim}$ \\
\hline 7 & $5 \cdot()$ & $4 \cdot 2$ & $1 \cdot()$ & $2 \cdot 2$ & $2 \cdot 8$ & 40 & 40 & 0 & 211 & 196 & 854 & 33 & 2.9 & ? \\
\hline 8 & $5 \cdot 1$ & 4.1 & $1 \cdot 3$ & $1 \cdot 8$ & $2 \cdot 3$ & 33 & 38 & 1 & 171 & $28 \cdot 10$ & 1004 & 41 & $2 \cdot 1$ & 二 \\
\hline () & $5 \cdot 1$ & $4 \cdot 3$ & 1.5 & 1.5 & $2 \cdot 6$ & 41 & 45 & 0 & 27.3 & 2710 & 11515 & 51 & 3.6 & $\vec{\omega}$ \\
\hline 10 & $5 \cdot 5$ & $5 \cdot()$ & $1 \cdot 5$ & $1 \cdot 3$ & $3 \cdot 8$ & - & - & () & 221 & 228 & 11511 & 44 & $1 \cdot 6$ & ఠ \\
\hline 11 & \multicolumn{5}{|c|}{ Impossible: lung metastases } & 38 & 43 & 9 & 3010 & $28 \quad 12$ & 8013 & 一 & $2 \cdot 5$ & $\stackrel{\jmath}{\beth}$ \\
\hline
\end{tabular}

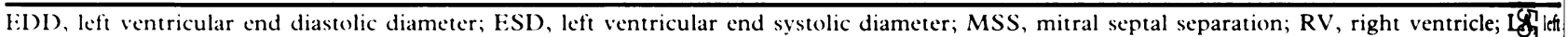
atrium; RA, right atrium; PA, pulmonary artery; I.VEF". ., left ventricular ejection fraction.

apart from the information that the patient had been treated with an antineoplastic drug. These grades are essentially: (1) occasional isolated myocytes showing myofibrillar loss or sarcoplasmic swelling; (2) more widespread changes with clusters of affected myocytes; (3) necrotic cells with nuclear and mitochondrial degeneration. Although fibrosis is a myocardial sequela of doxorubicin treatment, it is not used in the scoring because it is a non-specific reaction that can also be a side effect of radiation treatment.

Informed consent was obtained from all patients before the invasive diagnostic procedures.

\section{Results}

Eight patients had been treated with doxorubicin and three with a derivative (4'-epidoxorubicin) for three weeks. Seven patients received combination chemotherapy with cyclophosphamide and/or 5 -fluorouracil or vincristine. The mean cumulative doxorubicin dose was $552 \mathrm{mg} / \mathrm{m}^{2}$ body surface area (range $530-575 \mathrm{mg}$ ). The $4^{\prime}$-epidoxorubicin dose in patients 2,7 , and 11 was 360,1533 , and $645 \mathrm{mg} / \mathrm{m}^{2}$ respectively. Table 2 shows the echocardiographic, scintigraphic, and catheterisation data.

\section{ECHOCARDIOGRAPHIC DATA}

Echocardiograms in nine patients generally showed modest dilatation of the left ventricle especially at end systole (mean $4.3 \mathrm{~cm}$ ), whereas the diameter at end diastole was generally normal (mean $5.2 \mathrm{~cm}$ ). There was also considerable reduction in contractility and asynchronous or paradoxical septal movement (Fig. 1). Small pericardial (two patients) or pleural effusions (two patients) were also seen. In two patients the echocardiograms were poor because of lung metastases, and further calculations were im= possible.

\section{SCINTIGRAPHIC AND ANGIOGRAPHIC \\ DATA}

Left ventricular ejection fractions calculated fromp the gated blood pool scans ranged from $18^{\circ}{ }^{\circ}$, to $47^{\circ} \circ$ (mean $\left.32^{\prime \prime}{ }^{\prime}\right)$; these values were unchanged during subsequent supine exercise (at a maximum work load of $50 \mathrm{~W}$ ). Left ventricular cineangiograms in
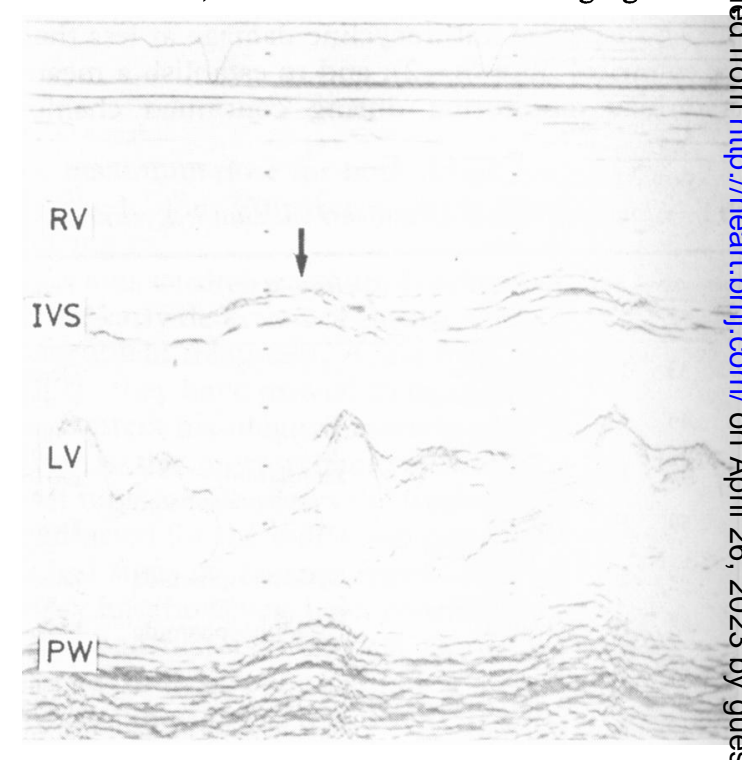

Fig. $1 M$ mode echocardiogram from case 5. The left ventricle $(L V)$ is moderately enlarged at end systole with increased mitral-septal separation and reduced contractility. The numerical result for fractional shortening (probably about $\left.15^{\circ} "\right)$ is unreliable because of paradoxical septal movement (arrow). RV, right ventricle; IVS, intraventricular septum; $P W$, posterior wall of left ventricle 


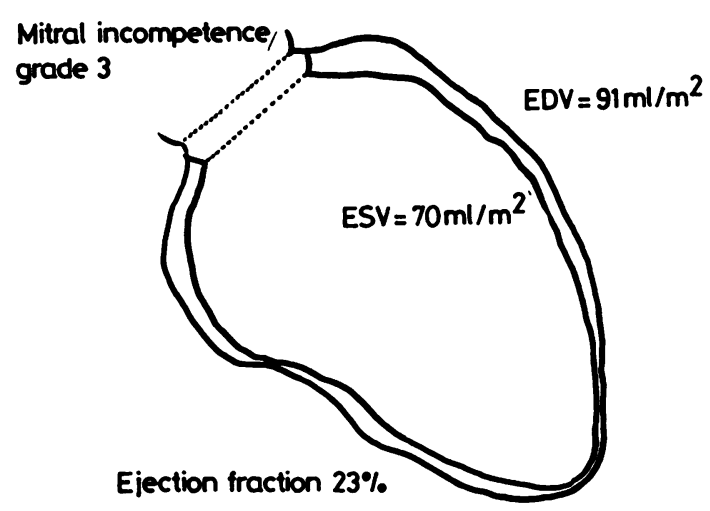

Fig. 2 End systolic and end diastolic frames from the left ventricular angiograms of case 5 showing a poorly contracting ventricle with an ejection fraction of $23^{\circ}{ }_{0}$. Severe mitral regurgitation (grade 3/4) was present despite the ventricle being only moderately dilated. EDV, end diastolic volume; ESV, end systolic volume.

eight patients showed a rigid contraction pattern in two and severe mitral incompetence in one (case 5) (Fig. 2). None of the patients showed clinical evidence of concomitant ischaemic heart disease-that is they did not have angina pectoris or myocardial infarction. Non-selective coronary arteriography obtained during contrast injection of the aortic root did not show any evidence of important lesions of the major epicardial coronary arteries.

\section{PRESSURE MEASUREMENTS}

In nine of the 11 patients pressure tracings obtained during catheterisation showed a pseudo-dip and plateau configuration in diastole ${ }^{1718}$ in the left or the right ventricle or both (Fig. 3). Right ventricular early diastolic dip was seen in five patients, and a diastolic plateau was indicated in two. Seven pa- tients showed diastolic dip in the left ventricle and one patient showed a tendency to a plateau. There was a diastolic dip in three patients and a suggestion of a plateau in one, in the pressure curve from both ventricles. Prominent a waves, ${ }^{17}$ (that is "atrial kick", an indirect indication of reduced ventricular compliance) were seen in nine of 11 patients; in the right ventricle in four, in the left ventricle in two, and in both ventricles in three.

\section{ENDOMYOCARDIAL BIOPSY DATA}

Light microscopy of cardiac biopsy specimens showed considerable fibrous thickening of the endocardium in 10 of the 11 patients, particularly in samples from the left ventricle (Table 3). Only four of eight patients had some degree of endocardial fibrosis in samples of the right ventricular septum. The endocardial thickening was due to collagenous tissue, possible with some smooth muscle cell deposition (Fig. 4). No inflammatory cells were seen in the endocardial zone, and organised mural thrombi were only seen in the left ventricle of one patient (case 4). The myocardium was generally characterised by cellular hypertrophy (both fibres and nuclei) and concomitant attenuation. The myocytes were regularly arranged without signs of disarray. Degenerative changes (with loss of myofibrils and vacuolation of the cytoplasm) were seen in the most severe cases, such as case 3 . The amount of interstitium was generally increased; in case 3 replacement fibrosis was also seen. The vessels appeared to be normal, and there were no signs of inflammation.

Electron microscopic studies of biopsy material from nine patients generally showed swelling and increased numbers of mitochondria (Fig. 5). Nuclear crenation, intracellular oedema, and mitochondriosis were non-specific, since similar changes were seen in biopsy specimens in two male controls (aged 50 and 47 years) before start of chemotherapy.

Table 3 Endomyocardial biopsy data in 11 patients with anthracycline cardiotoxicity

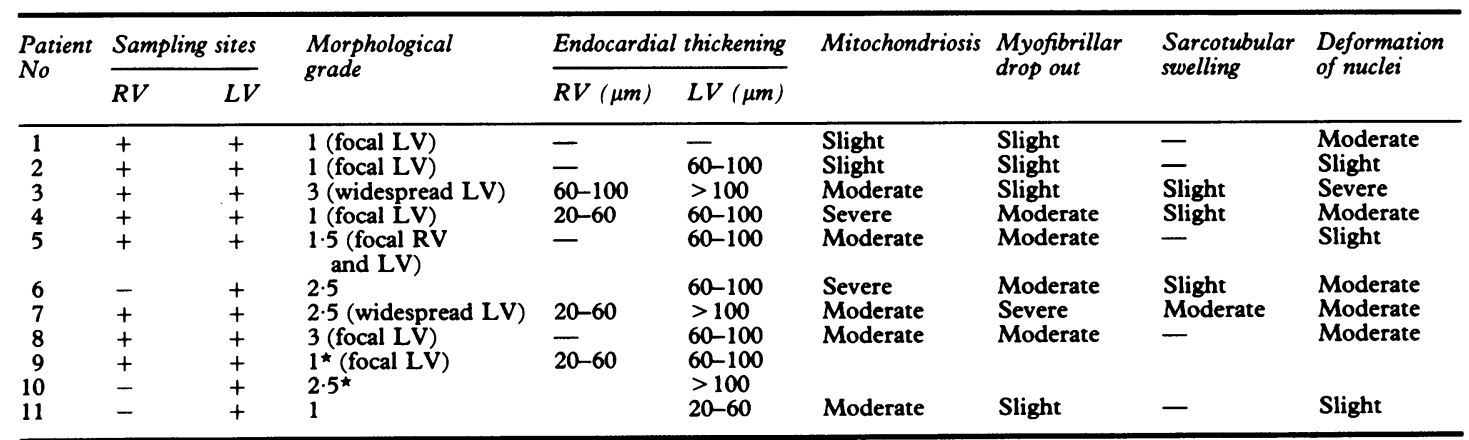

^Light microscopy.

RV, right ventricle; $L V$, left ventricle. 

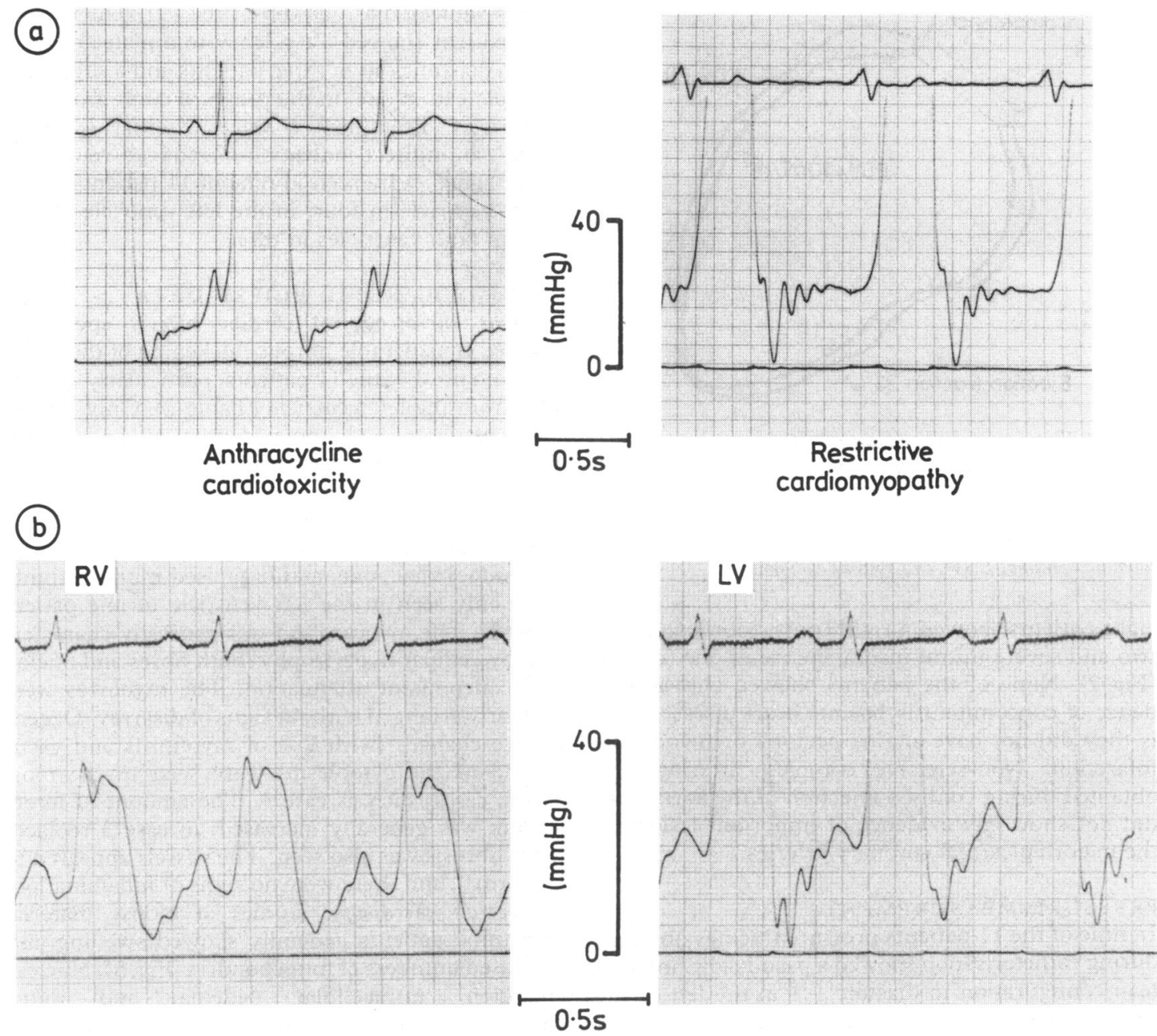

Fig. 3 (a) Left ventricular pressure tracings from case 8 with doxorubicin cardiotoxicity (left) and a 36 year old woman with restrictive cardiomyopathy (right). There is a tendency to a diastolic dip and plateau configuration in case 8 . The a wave is not present in the curve from the idiopathic case (right) with atrial fibrillation. (b) Pressure tracings from case 5 showing a waves and protodiastolic dip in the left ventricle. $R V$, right ventricle; $L V$, left ventricle.

Such changes have been shown to be non-specific markers of cardiac hypertrophy. ${ }^{19}$ Disruption of the myofibrils and myofibrillar "drop out" were seen in eight patients (Fig. 6) and four patients showed focal sarcotubular swelling (Fig. 7)-all characteristic signs of chronic anthracycline cardiotoxicity. ${ }^{3}$

\section{HISTOLOGICAL FINDINGS IN THE LEFT AND RIGHT VENTRICLES}

In eight patients in whom bilateral biopsy specimens were obtained, morphological damage was more pronounced in the left ventricle; this was especially true of endocardial thickening (in seven of eight cases) and also myocardial changes (in four of eight cases). Four patients had a normal right ventricular endocardium, and in one (case 8) the right ventricular biopsy specimens were completely normal, whereas the left ventricular biopsy specimens showed moderate damage. The most severe endocardial fibrosis of the left ventricle $(408 \mu \mathrm{m}$; normal thickness $<20 \mu \mathrm{m}^{16}$ ) was seen in a patient (case 3) who had had radiation to the mediastinum. 

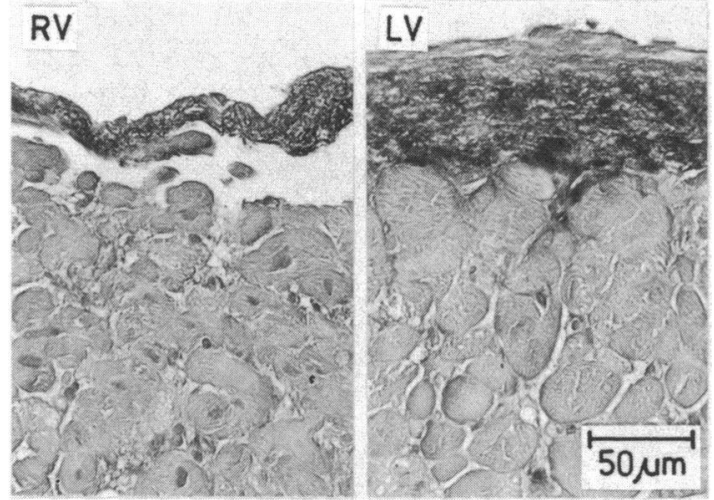

Fig. 4 Photomicrograph of endomyocardial biopsy specimens from case 5 showing normal endocardium in the right ventricle $(R V)$ and fibrous thickening of the endocardium in the left ventricle $(L V)$. (elastic van Gieson stain.)

\section{NECROPSY MATERIAL}

Tissue was obtained from a patient (case 1) who died of pancreatic carcinoma in hospital one week after catheterisation. The histological appearance of the endomyoca dial biopsy specimens from this patient correlated well with the degree of damage observed in multiple sections from the myocardium (Billingham grade 1 ).

\section{Discussion}

In this study we have attempted to define the haemodynamic and histological features that are typical

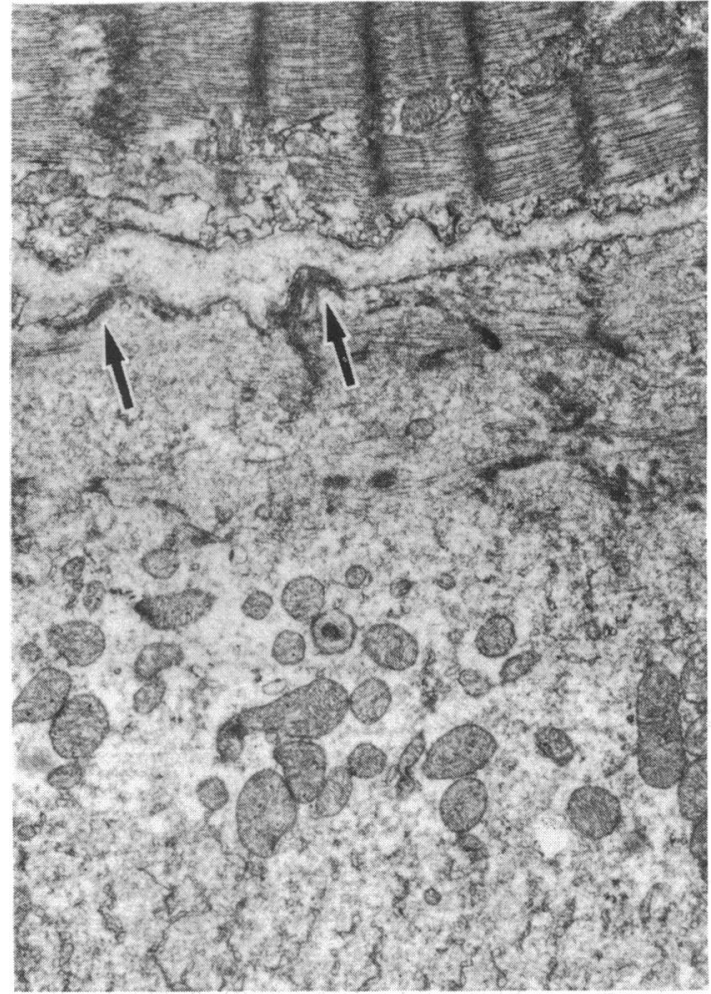

Fig. 6 Electron micrograph (case 6) showing a myocyte with preserved myofibrils at the top, and at the bottom myocytic degeneration with myofibrillar loss and small $z$ band fragments (arrows) along the inner cell membrane ( $z$ band lateralisation) $(\times 4800)$.
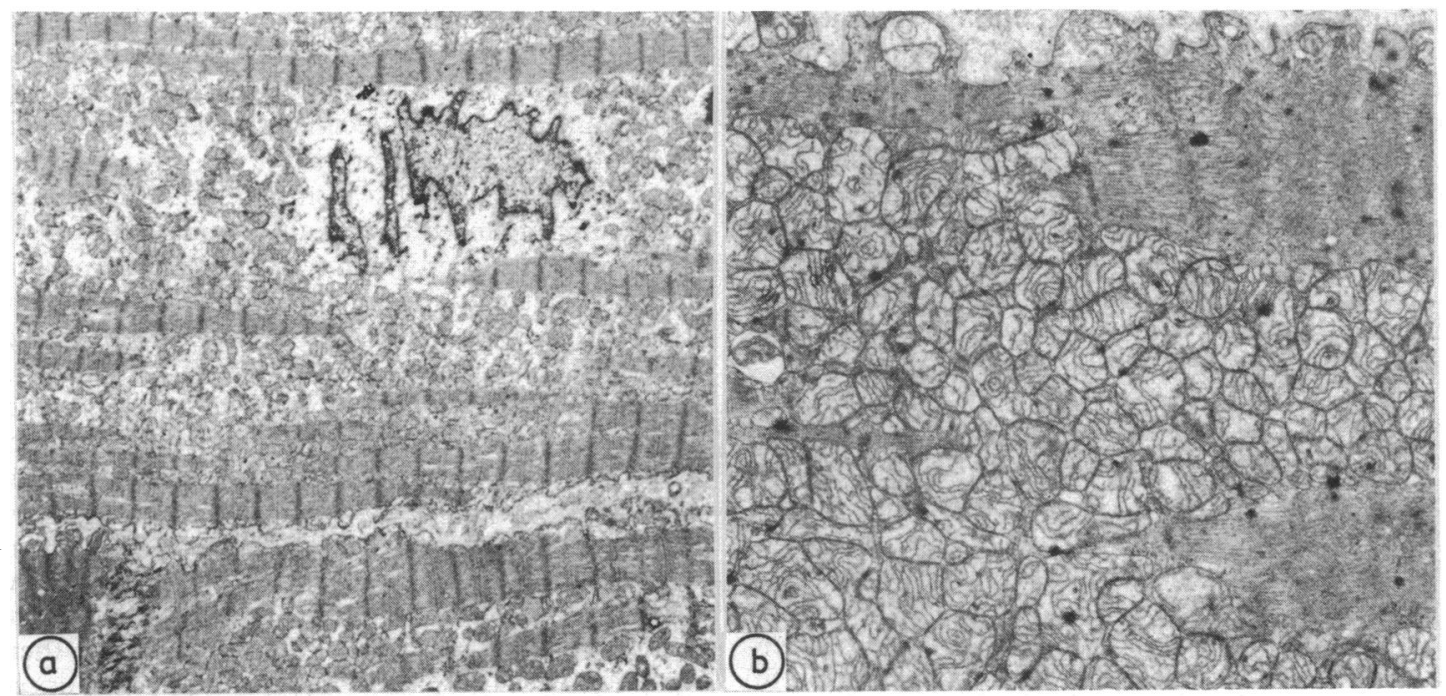

Fig. 5 Electron micrographs of an endomyocardial biopsy specimen from case 6 showing: (a) nuclear crenation, increased number of mitochondria (mitochondriosis), and some intracellular oedema $(\times 1500)$; (b) mitochondriosis at a higher magnification $(\times 4800)$ in another area. 


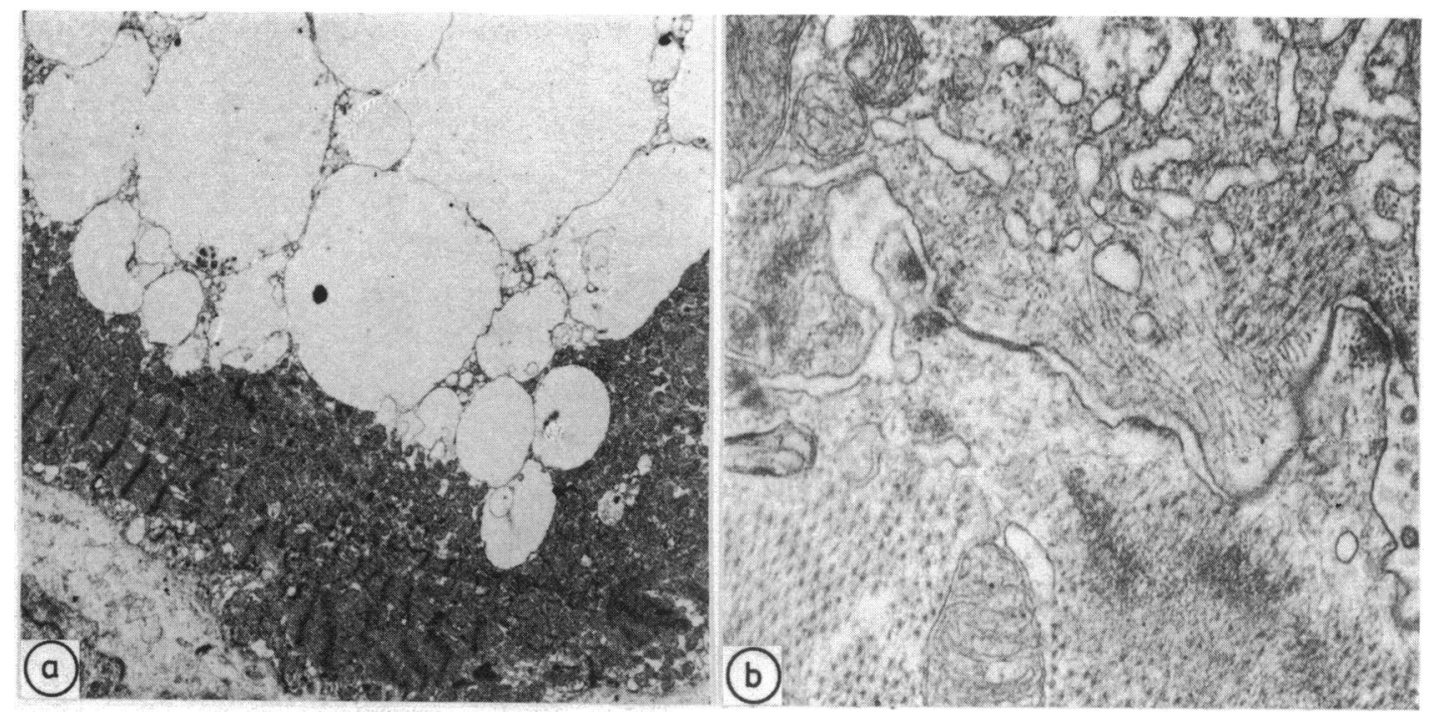

Fig. 7 Electronmicrographs of endomyocardial biopsy specimens from case 7 showing: (a) a single myocyte with extreme dilatation of the sarcotubular system (toluidine blue $\times 1000$ ); and (b) the presence of the same feature, but to a lesser degree, at the level of an intercalated disc $(\times 20000)$.

of clinically overt anthracycline cardiotoxicity. The prognosis of patients with this iatrogenic disorder is poor ${ }^{2}$ and many are almost untreatable.

As in a previous study, ${ }^{3}$ we found no evidence of acute or chronic inflammation in the endomyocardial biopsy specimens and we therefore did not use immunosuppressants. ${ }^{20}$ Morphological investigations of endomyocardial biopsy material from the right ventricular septum are a reliable means of monitoring cardiac damage during anthracycline treatment. Such monitoring has meant that some patients have been able to receive over $1000 \mathrm{mg} / \mathrm{m}^{2}$ of doxorubicin. ${ }^{21}$

Myocytic changes, which are most clearly seen by electron microscopy, are the characteristic histopathological features of doxorubicin damage. The density of these lesions correlates linearly with cumulative dose. Their severity has been graded on the Billingham score ${ }^{3}$ on a scale from 0 (no cells affected) to 3 (severe morphological damage).

Data obtained during right heart catheterisation (at rest and during exercise) suggest a non-linear (parabolic) relation between electronmicroscopic changes and the degree of haemodynamic impairment. Some degree of tissue damage may be present without equivalent haemodynamic signs of impairment, and heart failure occurs only at a certain critical morphological threshold. ${ }^{22}$ These myocardial doxorubicin lesions, which have been useful for adjusting the dosage of doxorubicin in individual patients, were present in most of our patients. Thus, the electronmicroscopic picture usually found during the period of doxorubicin treatment ${ }^{37}$ had not disappeared when our patients were investigated mean 2.7 months (range 0-5.5) after discontinuation of chemotherapy. Apparently, biopsy grading of cardiac damage based on material from the right ventricle $^{21-23}$ is the most sensitive and specific method for assessing doxorubicin cardiotoxicity. Eight of our patients had biopsy examination of both ventricles, and the degree of myocardial damage was most pronounced in samples from the left ventricle. This suggests that a false negative assessment may be obtained if biopsy specimens are taken only from the right ventricular septum.

Surprisingly, results from all but one patient showed pronounced fibrous thickening of the endocardium, a disorder which was most pronounced in the left ventricle (means $48 \mu \mathrm{m}$ and $138 \mu \mathrm{m}$ in the right and left ventricles, respectively). This observation had already been made indirectly in the catheterisation laboratory at biopsy when it was rather difficult to excise tissue specimens with the bioptome. The mechanisms by which anthracycline cardiotoxicity leads to endocardial fibrosis are obscure. Until now endocardial fibrosis has been described in only a few case reports, ${ }^{910}$ and such damage may have been attributed to radiation damage. Only one of our patients (case 3 ) had received radiation therapy, however; this patient had the most pronounced endocardial fibrosis. Methysergide has been reported to cause endomyocardial fibrosis, ${ }^{24}$ as has 
long term treatment with certain antineoplastic drugs such as busulfan ${ }^{25}$ in rare cases.

The explanation that endocardial thickening is secondary to dilatation of the ventricles, which is a common finding in dilated cardiomyopathy, ${ }^{16}$ is certainly inadequate in our patients who had only modest cavity enlargement. Endocardial lesions with a patchy distribution may resemble the changes seen in carcinoid heart disease that seem to be related to an excess of circulating serotonin. ${ }^{26}$ Hormonal mechanisms, such as histamine mediated damage, ${ }^{27}$ may have been involved in anthracycline related endocardial fibrosis in our study, in which left ventricular involvement predominated (unlike the predominantly right ventricular involvement found in carcinoid heart disease).

Eosinophilic cells, which are found in endocardial fibrosis caused by Löeffler's endomyocardial disease, ${ }^{28}$ were not detected in our biopsy specimens. In Löeffler's endomyocardial disease damage is apparently caused by eosinophilic cationic proteins. Cardiotoxic factors produced by certain tumours, such as circulating humoral substances, may be one of the factors giving rise to both myocardial and endocardial lesions. ${ }^{29}$

To our knowledge this is the first published report of endocardial fibrosis in a series of patients who have had anthracycline treatment. The value of a diagnosis of endocardial thickening in monitoring cancer patients during treatment with anthracyclines remains to be established. Endocardial thickening may, however, be the first morphological sign of cardiotoxicity. This accords with reports that myocardial changes first appear in the subendocardium (Billingham ME, personal communication). Our data and the outcome of treatment of heart failure in cases of overt cardiotoxicity, do not suggest that endomyocardial biopsy has any recognisable consequences. The procedure seems justified only in cases of latent cardiotoxicity ${ }^{12}$ when the possible development of chronic cardiotoxicity is being considered. We found that initial clinical status (New York Heart Association functional class) correlated with morphological grading (Billingham score)-that is the higher the pathological score the worse the clinical status (Tables 1 and 3 ).

The endomyocardial data and echocardiographic findings (that is a modest dilatation of the left ventricle) and the pressure curves seem to indicate that overt anthracycline cardiotoxicity is to some extent a restrictive endomyocardial disease. This may have therapeutic implications. For example vasodilator agents should be given with caution. Conversely, coenzyme Q-10 may be used without additional risk to improve cardiac function. ${ }^{30}$
CONCLUSION

Chronic anthracycline cardiotoxicity, which has been classified as a dilated heart disease (mimicking congestive cardiomyopathy), seems to be characterised by pronounced endocardial fibrosis. Morphological observations, mainly from the left ventricle of patients who had not received radiotherapy, together with echocardiographic and haemodynamic data, suggest that anthracyclines can mediate a toxic endocardial disorder. When this heals restrictive endomyocardial disease develops in parallel with certain characteristic myocardial effects. Pronounced endocardial fibrosis, however, has been seen in patients with low grade myocardial damage; and the changes may not be detected when investigations are made of the right ventricle only. The present observations may contribute to the understanding of the obscure pathogenesis of anthracycline cardiotoxicity, and may be useful in modifying the treatment of patients with anthracycline induced heart failure.

\section{References}

1 Lefrak EA, Pitha J, Rosenheim S, Gottlieb JA. A clinicopathologic analysis of adriamycin cardiotoxicity. Cancer 1973; 32: 302-14.

2 Von Hoff DD, Layard MW, Basa P, et al. Risk factors for doxorubicin-induced congestive heart failure. $A n n$ Intern Med 1979; 91: 710-7.

3 Billingham ME, Mason JW, Bristow MR, Daniels JR. Anthracycline cardiomyopathy monitored by morphologic changes. Cancer Treat Rep 1978; 62: 865-72.

4 Oki T, Takeuchi T, Oka S, Umezawa H. New anthracycline antibiotic aclacinomycin A: experimental studies and correlations with clinical trials. Recent Results Cancer Res 1981; 76: 21-40.

5 Young CW. Epirubicin: a therapeutically active doxorubicin analogue with reduced cardiotoxicity. In: Bonadonna G, ed. Advances in anthracycline chemotherapy: Epirubicin. Milano: Masson Italia Editori, 1984: 183-8.

6 Chlebowski RT. Adriamycin (doxorubicin) cardiotoxicity: a review. West $\mathcal{F}$ Med 1979; 131: 364-8.

7 Mason JW, Bristow MR, Billingham ME, Daniels JR. Invasive and noninvasive methods of assessing adriamycin cardiotoxic effects in man: superiority of histopathologic assessment using endomyocardial biopsy. Cancer Treat Rep 1978; 62: 857-64.

8 Ewer MS, Ali MK, Mackay B, et al. A comparison of cardiac biopsy grades and ejection fraction estimations in patients receiving adriamycin. Fournal of Clinical Oncology 1984; 2: 112-7.

9 Kantrowitz NE, Bristow MR. Cardiotoxicity of antitumor agents. Prog Cardiovasc Dis 1984; 27: 195-200.

10 Conroy B, Guthrie W. Endocardial fibroelastosis associated with fatal adriamycin (doxorubicin) cardiomyopathy during treatment of Ewing's sarcoma. Scott 
Med f 1983; 28: 295-9.

11 Bertazzoli C, Dell'Oro I, Ferni G, Rovero C, Solcia E. Adriamycin experimental cardiotoxicity in the rabbit. IRCS Med Sci 1974; 2: 1454.

12 Mortensen SA, Aabo K, Jonsson T, Baandrup U. Clinical and non-invasive assessment of anthracycline cardiotoxicity. Perspectives on myocardial protection. Int f Clin Pharmacol Res 1986 (in press).

13 Feigenbaum H, ed. Echocardiography. Philadelphia: Lea and Febiger, 1981: 3.

14 Bardy A, Fouyé H, Gobin R, et al. Technetium-99m labelling by means of stannous pyrophosphate: application to bleomycin and red blood cells. $\mathcal{F}$ Nucl Med 1975; 16: 435-7.

15 Richardson PJ. King's endomyocardial bioptome. Lancet 1974; i: 660-1.

16 Baandrup U. Endomyocardial biopsy in suspected cardiomyopathy - a morphological and morphometric analysis. University of London, 1979. Thesis.

17 Goodwin JF. Diastolic heart disease. In: Maseri A, ed. Hammersmith Cardiology Workshop Series. New York: Raven Press, 1985; 2: 13-7.

18 Oakley CM. Amyloid heart disease. In: Goodwin JF, ed. Heart muscle disease. Lancaster: MPT Press, 1985: $141-53$.

19 Baandrup U, Florio RA, Roters F, Olsen EGJ. Electron microscopic investigation of endomyocardial biopsy samples in hypertrophy and cardiomyopathy. A semiquantitative study in 48 patients. Circulation 1981; 63: 1289-98.

20 Mason JW, Billingham ME, Ricci DR.' Treatment of acute inflammatory myocarditis assisted by endomyocardial biopsy. Am f Cardiol 1980; 45: 1037-44.

21 Bristow MR, Lopez MB, Mason JW, Billingham ME, Vinchester MA. Efficacy and cost of cardiac monitoring in patients receiving doxorubicin. Cancer 1982; 50: 32-41.

22 Bristow MR, Mason JW, Billingham ME, Daniels JR. Dose-effect and structure-function relationships in doxorubicin cardiomyopathy. Am Heart $f$ 1981; 102: 709-18.

23 McKillop JH, Bristow MR, Goris ML, Billingham ME, Bockemuehl K. Sensitivity and specificity of radionuclide ejection fraction in doxorubicin cardiotoxicity. Am Heart f 1983; 106: 1048-56.

24 Harbin AD, Gerson MC, O'Connell JB. Simulation of acute myopericarditis by constrictive pericardial disease with endomyocardial fibrosis due to methysergide therapy. $\mathcal{A}$ Am Coll Cardiol 1984; 4: 196-9.

25 Weinberger A, Pinkhas J, Sandbank U, Shaklai M, De Vries A. Endocardial fibrosis following busulfan treatment. IAMA 1975; 231: 495.

26 Ferrans VJ, Roberts WC. The carcinoid endocardial plaque. Hum Pathol 1976; 7: 387-408.

27 Bristow MR, Minobe WA, Billingham ME, et al. Anthracycline-associated cardiac and renal damage in rabbits. Evidence for mediation by vasoactive substances. Lab Invest 1981; 45: 157-68.

28 Olsen EGJ, Spry CJF. The pathogenesis of Löffler's endomyocardial disease, and its relationship to endomyocardial fibrosis. In: Yu PN, Goodwin JF, eds. Progress in cardiology. Philadelphia: Lea and Febiger, 1979; 8: 281-303.

29 Mir MA. A cardiotoxic factor in serum and blast cell extract of patients with acute myeloid leukaemia. Cardiovasc Res 1981; 15: 365-72.

30 Judy WV, Hall JH, Dugan W, Toth PD, Folkers K. Coenzyme Q-10 reduction of adriamycin cardiotoxicity. In: Folkers K, Yamamura Y, eds. Biomedical and clinical aspects of coenzyme $Q$. Amsterdam: Elsevier Science Publishers BV, 1984; 4: 231-41. 